\title{
Transforming Growth Factor-Beta 1 Gene Polymorphism in Tuberculosis Patients
}

\author{
Vijay Kumar, Rajiv Khosla, Ajay Kumar, Vikas Gupta and B.C. Sarin ${ }^{1}$ \\ Department of Molecular Biology and Biochemistry, Guru Nanak Dev University, Amritsar, \\ Punjab, India \\ ${ }^{1}$ Department of TB and Chest, Sri Guru Ram Das Institute of Medical Sciences and Research, \\ Amritsar 143 002, Punjab, India
}

KEYWORDS TGF- $\beta 1$; tuberculosis; single nucleotide polymorphism; ARMS-PCR; cytokine

\begin{abstract}
Tuberculosis (TB) is a curable infectious disease that kills around half million individuals every year in India. Cytokines play a vital role in the pathogenesis of this deadly disease. Transforming growth factor-beta 1 (TGF$\beta 1$ ) is one of the important anti-inflammatory cytokine found to be elevated in TB patients. Single nucleotide polymorphisms (SNP) in the promoter of TGF- $\beta 1$ cytokine gene are known to alter the production of this important cytokine. Given its immunosuppressive nature increased production of this cytokine is implicated towards susceptibility to TB. The $\mathrm{C} / \mathrm{T}$ polymorphism in TGF- $\beta 1$ promoter at -509 site is strongly associated with circulating levels of this cytokine and $\mathrm{T}$ allele is shown to be associated with its high production. Thus, in the present study we looked for association of TGF- $\beta 1$ (C-509T) SNP with TB. A total of 245 subjects (145 TB patients and 100 normal healthy controls) were recruited for study. The -509 polymorphism was studied using Amplification Refractory Mutation System- Polymerase Chain Reaction (ARMS-PCR). The distribution of C/T alleles in TB patients and normal healthy controls did not reveal any statistically significant association of this polymorphism with TB $\left(\chi^{2}=0.04 ; p=0.85\right)$.
\end{abstract}

\section{INTRODUCTION}

Approximately two billion individuals globally are infected with Mycobacterium tuberculosis, yet only $10 \%$ of them develop clinical tuberculosis (TB). This can be attributed to the host genetic factors, which play an important role in development of clinical disease following infection with this deadly pathogen (Awomoyi et al. 2004). A growing body of evidence indicates that both the risk of acquiring infection and risk of developing severe complications are related to genetic variability at cytokine loci (McNicholl et al. 2000). In this regard, it has been shown that polymorphisms in genes encoding for different cytokines are associated with TB (LopezMaderuelo et al. 2003).

Transforming growth factor-beta 1 (TGF- $\beta 1$ ) has important anti-inflammatory effects (Kehrl et al. 1986) and is increased in serum of patients with advanced TB (Fiorenza et al. 2004). Monocytes from TB patients secrete increased

${ }^{I}$ Corresponding Author: Dr B.C. Sarin, MD Associate Professor, Department of TB and Chest, Sri Guru Ram Das Institute of Medical Sciences and Research, Amritsar 143 002, Punjab, India

Telephone: +919417425031

E mail: bcsarin@yahoo.com amount of TGF- $\beta 1$ upon in vitro stimulation with mycobacterial antigen (Olobo et al. 2001). Langerhans giant cells and epitheloid cells in TB granulomas express increased levels of TGF- $\beta 1$ mRNA suggesting local production of it may result in deactivation of macrophages leading to immunopathology of the disease (Toosi et al. 1995). In TB, TGF- $\beta 1$ increases intracellular growth of $M$. tuberculosis whereas neutralizing antibody to TGF- $\beta 1$ reduces intracellular growth (Hirsch et al. 1994). Thus, it is conceivable that allelic variations in the promoter of TGF- $\beta 1$ gene resulting in altered protein production might be responsible for differential TB pathogenesis among individuals. The C-509T polymorphism in TGF- $\beta 1$ promoter is associated with circulating levels of this cytokine. Additionally, the T allele is shown to be associated with high production of TGF- $\beta 1$ (Grainger et al. 1999). The present study was conducted to evaluate the association of C-509T allele polymorphism and susceptibility to tuberculosis in Punjabi population of North India.

\section{MATERIALS AND METHODS}

Study Population: The study population consisted of 145 TB patients (confirmed by 
physician) and 100 normal healthy control subjects. Informed consent was taken from all the individuals participating in the study. Information related to name, age, sex, ethnic origin and family history was collected from the patients. Venous blood samples from patients were collected in storage vials containing EDTA as an anticoagulant, visiting Department of TB and Chest, Sri Guru Ram Das Institute of Medical Sciences and Research, Amritsar; TB and Chest hospital, Government Medical College, Amritsar; TB and Chest Wing, Civil Hospital, Gurdaspur, Punjab.

DNA Extraction and Genotyping TGF- $\beta 1$ (C-509T) Polymorphism: DNA was extracted from peripheral blood using modified inorganic method (Miller et al. 1988). Extracted DNA was quantified using UV-Spectrophotometry. The polymorphism for TGF- $\beta 1$ C-509T allele was genotyped using Amplification Refractory Mutation System-Polymerase Chain Reaction (ARMS-PCR) method developed in our laboratory. Briefly, two complementary reactions were established for each allele consisting of target DNA; allele specific ARMS primers (RC for $\mathrm{C}$ allele and RT for T allele) and the common primer (CF). A 349 base pair region (nt - 488 to 836 from the transcription start site) in the TGF$\beta 1$ gene promoter was targeted for amplification. The characteristics of primer sequences are shown in table 1 . To assist in the genotyping of -509 polymorphism, the penultimate base in the primers RC and RT was mutated from A to $\mathrm{G}$. The optimized reaction conditions consisted of $40 \mathrm{ng}$ of genomic DNA in a reaction volume of $30 \mu 1$, containing $0.16 \mu \mathrm{M}$ of each primer, $30 \mu \mathrm{M}$ of each dNTP, $10 \mu \mathrm{M}$ Tris- $\mathrm{HCl}(\mathrm{pH} 9.0), 1.5 \mu \mathrm{M} \mathrm{MgCl}_{2}$, $50 \mu \mathrm{M} \mathrm{KCl}, 0.01 \%$ gelatin and $0.3 \mathrm{U}$ of Taq DNA polymerase. Amplification was carried out for 35 cycles, each cycle consisting of denaturation at $94^{\circ} \mathrm{C}$ for $30 \mathrm{~s}$, annealing at $61^{\circ} \mathrm{C}$ for 20 s, extension at $72^{\circ} \mathrm{C}$ for $20 \mathrm{~s}$ and finally a 3 min extension at $72^{\circ} \mathrm{C}$. The amplified PCR products were analyzed by agarose gel electrophoresis on a $2 \%$ agarose gel stained with ethidium bromide. Known positive and negative controls were included in each batch of amplification.
Statistical Analysis: Allelic and genotypic frequencies in TB patients and normal healthy control population were compared using $2 \times 2$ contingency tables and chi-squared $\left(\chi^{2}\right)$ statistics. Statistical significance was defined at the standard 5\% level.

\section{RESULTS}

A total of 245 subjects (145 TB patients and 100 normal healthy subjects) were genotyped for C-509TTGF- $\beta 1$ polymorphism, by ARMS-PCR. A representative gel photograph showing various genotypes of C-509T polymorphism are shown in figure 1 . The sample was labeled CC or TT genotype, if a 349 bp band was observed only with $\mathrm{C}$ or $\mathrm{T}$ allele specific primer, respectively. However, if bands were observed with both allele specific primers then the sample was labeled with CT genotype. A known positive and negative control was included in each set of amplification. For example, for a $\mathrm{C}$ allele specific primer a known $\mathrm{CC}$ genotype worked as positive control and TT genotype served as a negative control, similarly a T allele specific primer will not amplify target DNA having $\mathrm{CC}$ genotype but give positive results with other two (CT, TT) genotypes. Tuberculosis and control populations were found to be in HardyWeinberg equilibrium with chi square values of 1.14 and 0.78 , respectively. Table 2 shows distribution of TGF- $\beta 1$ polymorphism in studied populations. The frequency of various genotypes in both the groups was almost similar. TB patients had little more heterozygotes (49.7 vs 42.0\%) while the normal controls had a little higher frequency of CC genotype (43.0 vs $40.0 \%$ ). However, the difference in allele frequencies were statistically non significant between normal healthy control subjects and TB patients $\left(\chi^{2}=0.04 ; \mathrm{p}\right.$ value $=$ 0.85).

\section{DISCUSSION}

The extent to which progressive clinical TB is associated with genetic host factors remains

Table 1: Characteristics of C-509T TGF- $\beta 1$ polymorphism and primer sequences used for Amplification Refractory Mutation System-Polymerase Chain Reaction (ARMS-PCR) method.

\begin{tabular}{|c|c|c|c|}
\hline Location Allele & Primers & Sequence & Product Size \\
\hline TGF- $\beta 1$; Constant & Antisense (CF) & 5'CTACGGCGTGGAGTGCTGAG 3' & \multirow{3}{*}{$349 \mathrm{bp}$} \\
\hline TGF- $\beta 1 C ;$ ARMS & Sense (RC) & 5'AAGGGGCAACAGGACACCTGGG 3' & \\
\hline TGF- $\beta 1 \mathrm{~T} ;$ ARMS & Sense (RT) & 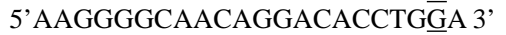 & \\
\hline
\end{tabular}




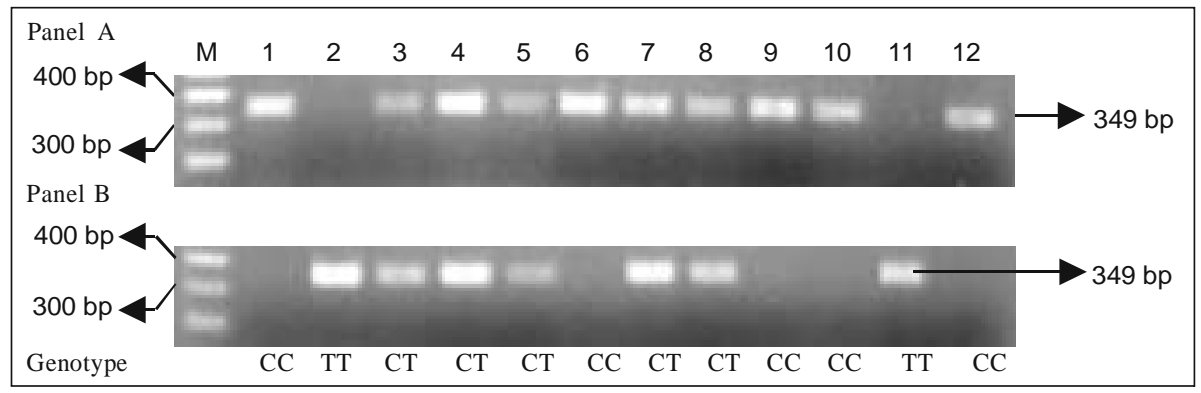

Fig. 1. A representative agarose gel photograph of the TGF- $\beta 1$ (C-509T) polymorphism. The panels A and $B$ depict the DNA samples amplified with $C$ allele specific and $T$ allele specific, primer pairs, respectively. Lane $M$ represents 100 bp ladder. Lane 11 and 12 correspond to control samples of TT and CC genotypes, respectively. Lanes 1 to 10 show random samples amplified. The genotypes of samples are given at the bottom of each lane.

Table 2: Genotype distribution and allele frequencies for TGF- $\beta 1$ (C-509T) SNP in studied population.

\begin{tabular}{|c|c|c|c|c|}
\hline \multirow[t]{2}{*}{ Population (n) } & \multicolumn{3}{|c|}{ Genotype frequencies (\%) } & \multirow{2}{*}{$\frac{\text { Allele frequencies }}{C / T}$} \\
\hline & $C C$ & $C T$ & $T T$ & \\
\hline TB patients (145) & $58(40.00)$ & $72(49.70)$ & $15(10.30)$ & $0.65 / 0.35$ \\
\hline Controls (100) & $43(43.00)$ & $42(42.00)$ & $15(15.00)$ & $0.64 / 0.36$ \\
\hline
\end{tabular}

$\chi^{2}$ based on allele frequency (degrees of freedom $\left.=1\right),($ TB patients Vs Controls) $=0.04 \quad \mathrm{p}$ value $=0.85$

unidentified in spite of large number of reports, which indicates association of clinical features of disease to host background (Scola et al. 2003). There is ample data to document that TGF- $\beta 1$ protein plays a vital role in the pathogenesis of TB. It has been shown to down regulate production of proinflammatory cytokines, deactivate macrophage function against $M$. tuberculosis and decrease responsiveness of Tcells to IL-2 (Kehrl et al. 1986; Shalaby et al. 1988; Wahl et al. 1988; Musso et al. 1990). Studies also demonstrate prominent role for TGF- $\beta 1$ in modulating production of IFN- $\gamma$ in patients with pulmonary TB (Hirsch et al. 1996) which is an important macrophage activating cytokine during infection with M. tuberculosis (Kamijo et al. 1993; Huang et al. 1993). TGF- $\beta 1$ is also known to suppress TNF- $\alpha$ production in human and murine macrophages (Espevik et al. 1987) which is required early to limit $M$. tuberculosis multiplication and is a crucial factor in elimination of TB (Olobo et al. 2001). In our study, we tried to find out the association between $\mathrm{T}$ allele of C509T polymorphism and susceptibility to tuberculosis, as it is associated with high circulating levels of this cytokine (Grainger et al.1999). However, results obtained from this study do not show any statistically significant difference for TGF- $\beta 1 \mathrm{C}-509 \mathrm{~T}$ polymorphism between TB patients and normal healthy controls in our population.

\section{ACKNOWLEDGEMENTS}

We are thankful to Dr P. K. Sehajpal for his guidance in the completion of this work. VK is thankful to UGC, New Delhi for the award of Junior Research Fellowship.

\section{REFERENCES}

Awomoyi AA, Nejentsev S, Richardson A, Hull J, Koch $\mathrm{O}$ et al 2004. No association between interferon- $\beta$ receptor-1 gene polymorphism and pulmonary tuberculosis in a Gambian population sample. Thorax, 59: 291-294.

Espevik T, Figari IS, Shalaby MR, Lackides GA, Lewis GD et al 1987. Inhibition of cytokine production by cyclosporin A and transforming growth factor beta. J Exp Med, 166: 571-576.

Fiorenza G, Rateni L, Farroni MA, Bogue C, Dlugovitzky DG 2005. TNF- $\alpha$, TGF- $\beta$ and NO relationship in sera from tuberculosis (TB) patients of different severity. Immunol lett, 98: 45-48.

Grainger DJ, Heathcote K, Chiano M, Snieder H, Kemp PR et al 1999. Genetic control of the circulating concentration of transforming growth factor type ß1. Hum Mol Genet, 8: 93-97. 
Hirsch CS, Hussain R, Toossi Z, Dawood G, Shahid F et al 1996. Cross-modulation by transforming growth factor $\beta$ in human tuberculosis: suppression of antigen-driven blastogenesis and interferon- $\gamma$ production. Proc Natl Acad Sci USA, 93: 31933198.

Hirsch CS, Yoneda T, Averill L, Ellner JJ, Toossi Z 1994. Enhancement of intracellular growth of Mycobacterium tuberculosis in human monocytes by transforming growth factor-beta 1 . J Infect Dis, 170: $1229-1237$.

Huang S, Hendriks W, Althage A, Hemmi S, Bluethmann $\mathrm{H}$ et al 1993. Immune response in mice that lack the interferon-gamma receptor. Science, 259: 17421745.

Kamijo R, Le J, Shapiro D, Havell EA, Huang S et al 1993. Mice that lack the interferon-gamma receptor have profoundly altered responses to infection with Bacillus Calmette-Guerin and subsequent challenge with lipopolysaccharide. J Exp Med, 178: 14351440 .

Kehrl JH, Wakefield LM, Roberts AB, Jakowlew S, Alvarez-Mon $M$ et al 1986. Production of transforming growth factor beta by human $\mathrm{T}$ lymphocytes and its potential role in the regulation of T cell growth. J Exp Med, 163: 1037-1050.

Lopez-Maderuelo D, Arnalich F, Serantes R, Gonzalez A, Codoceo R et al 2003. Interferon-gamma and interleukin-10 gene polymorphisms in pulmonary tuberculosis. Am J Respir Crit Care Med, 167: 970975.

McNicholl JM, Downer MV, Udhayakumar V, Alper CA, Swerdlow DL 2000. Host-pathogen interactions in emerging and re-emerging infectious diseases: a genomic perspective of tuberculosis, malaria, human immunodeficiency virus infection, hepatitis B, and cholera. Annu Rev Public Health, 21: 15-46.

Miller SA, Dykes DD, Polesky HF 1988. A simple salting out procedure for the extraction of DNA from human nucleated cells. Nucleic Acids Res, 16: 1215.

Musso T, Espinoza-Delgado I, Pulkki K, Gusella GL, Longo DL et al 1990. Transforming growth factor beta down regulates interleukin-1 (IL-1)-induced IL-6 production by human monocytes. Blood, 76: 2466-2469.

Olobo JO, Geletu M, Demissie A, Eguale T, Hiwot K et al 2001. Circulating TNF- $\alpha$, TGF- $\beta$ and IL-10 in tuberculosis patients and healthy contacts. Scand $J$ Immunol, 53: 85-91.

Scola L, Crivello A, Marino V, Gioia V, Serauto A et al 2003. IL-10 and TNF- $\alpha$ polymorphism in a sample of sicilian patients affected by tuberculosis : implication for ageing and life span expectancy. Mech Ageing Dev, 124: 569-572.

Shalaby MR, Ammann AJ 1988. Suppression of immune cell function in vitro by recombinant human transforming growth factor-beta. Cell Immunol, 112: $343-350$.

Toossi Z, Gogate P, Shiratsuchi H, Young T, Ellner JJ 1995. Enhanced production of TGF- $\beta$ by blood monocytes from patients with active tuberculosis and presence of TGF- $\beta$ in tuberculous granulomatous lung lesions. J Immunol, 154: 465-473.

Wahl SM, Hunt DA, Wong HL, Dougherty S, McCartneyFrancis $\mathrm{N}$ et al 1988. Transforming growth factorbeta is a potent immunosuppressive agent that inhibits IL-1-dependent lymphocyte proliferation. J Immunol, 140: 3026-3032. 